\title{
Residential Mortgage Loans Delinquencies Analysis and Risk Drivers Assessment
}

\author{
Aivars Spilbergs ${ }^{a^{*}}$ \\ ${ }^{a}$ Economics and Finance Department, BA School of Business and Finance, Riga, Latvia
}

\begin{abstract}
Residential mortgage loans play an important role in improving living conditions in developed countries. In Latvia, however, residential mortgage volumes have declined throughout the postcrisis year's and were at the end of $201812 \%$ below the end 2008 level, while the house price index ca. $25 \%$ below pre-crisis level. The main reasons for this are banks credit losses, which resulted in a revision of credit granting standards and a deteriorating in their availability. On the other hand, households have experienced increased uncertainty, both as a result of financial difficulties, experienced during the crisis years and political instability in the post-crisis years. It is therefore essential to identify the true risk drivers and to analyse them. Based on existing researches in other countries, the author has identified several dozen macro-economic indicators, such as the unemployment rate, wage growth, housing price index, etc. and micro factors such as the age of the borrower, total debt to income, loan-to-value, etc., have developed univariate and multivariate econometric models and have examined their statistical stability. Consequently, through a consistent application, it is possible to take sound credit decisions, both in banks and by households, and to contribute to the sustainable development of the housing market.
\end{abstract}

\section{Keywords:}

Econometric Models; Housing Loans;

Risk Drivers

Macro Level Risk Drivers;

Micro Level Risk Drivers.

Article History:

$\begin{array}{llll}\text { Received: } & 16 & \text { October } & 2019 \\ \text { Accepted: } & 10 & \text { February } & 2020 \\ & & & 2020\end{array}$

\section{1- Introduction}

In the last decade of the 20th century, and also in the first years of this century the residential mortgage loans market in Latvia was stagnant due to low household income level and high credit interest rates. Coming closer to join NATO and the EU, foreign investment flowed rapidly, the costs of bank resources declined and confidence in the long-term growth of household incomes strengthened. As a result, housing lending and the ratio of loans to GDP increased significantly, see Figure 1. Unfortunately, most of borrowers had no credit experience until then. Lack of understanding of the housing market, high inflation and overall euphoria lead to disproportionate against stable and regular income borrowing and disregarding of risks until mid-2007, when anti-inflation measures where approved by Latvian Cabinet of Ministers came into force. With the new framework loans granting fell sharply, followed with decrease in demand in housing market and much more difficult refinancing of existing commitments. In 2008 the impact of the global financial crisis on Latvia's financial market became critical, in the autumn the largest bank went bankrupt, GDP fell sharply and unemployment began to rise. As a result, the proportion of non-performing housing loans (HoNPL) increased rapidly - from $0.7 \%$ at the end of 2007 to $15.4 \%$ and $16.2 \%$ at the end of 2009 and 2010 , respectively [1]. Although HoNPLs have declined significantly starting from 2013 and have fallen below $2.5 \%$ at the end of 2018, the consequences are evident - at the end of last year housing loans volumes where $40 \%$ below pre-crisis level [2].

As residential mortgage loans play a key role in improving household living conditions, it is important to be aware of the main risk drivers and to work to prevent the mistakes that have been experienced in the past.

\footnotetext{
*CONTACT: Aivars.spilbergs@ba.lv

DOI: http://dx.doi.org/10.28991/esj-2020-01214
}

(C) 2020 by the authors. Licensee ESJ, Italy. This is an open access article under the terms and conditions of the Creative Commons Attribution (CC-BY) license (https://creativecommons.org/licenses/by/4.0/). 


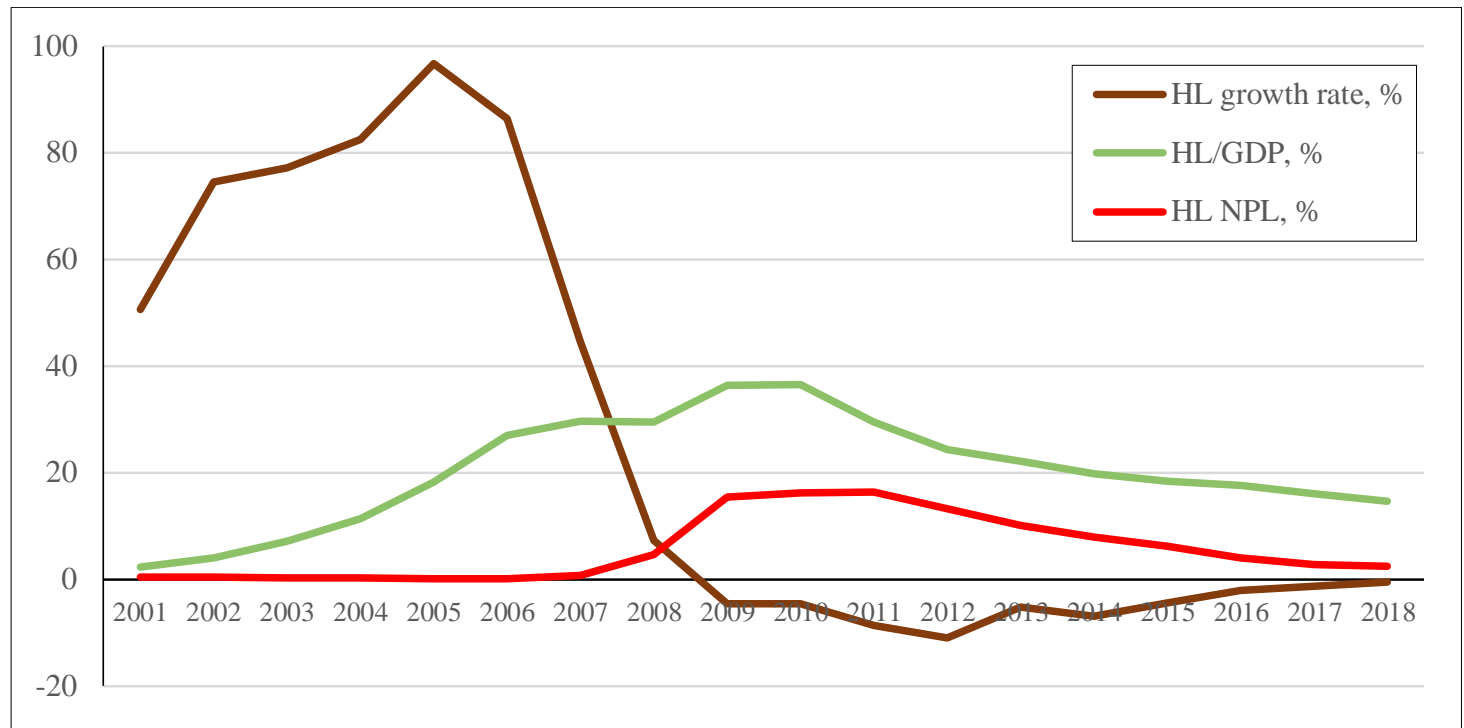

Figure 1. Housing loans growth rate, housing loans proportion to GDP and NPL development in Latvia (FCMC and CSB of Latvia data).

\section{2- Literature Review}

Studies on the residential mortgage loans delinquencies include wide variety of variables, which can be divided into three groups: borrower and transaction characteristics, and macroeconomic ones.

Table 1. Residential mortgage loans delinquencies affecting factors analysis summary from literature review.

\begin{tabular}{|c|c|c|}
\hline Group & Parameter & Author \\
\hline \multirow{6}{*}{ Borrower } & Age & $\begin{array}{l}\text { Avanzini (2015) [3]; Campbell (2015) [4]; Csizmady (2017) [5]; Gerlach-Kristen (2018) [6]; } \\
\text { Lydon (2013) [7]; Van Ooijena (2016) [8] }\end{array}$ \\
\hline & Credit score & $\begin{array}{l}\text { Elul (2010) [9]; Foote (2018) [10]; Fuster (2015) [11]; Goodman (2010) [12]; Gyourko } \\
\text { (2014) [13]; Harrison (2011) [14]; Jones (2015) [15]; Lee (2016) [16] }\end{array}$ \\
\hline & Debt service ratio & $\begin{array}{l}\text { Figueira (2005) [17]; Foote (2018) [10]; Harrison (2011) [14]; Jones (2015) [15]; Kelly } \\
\text { (2018) [18]; Kukk (2016) [19]; Lee (2016) [16]; Lydon (2013) [7]; Van Ooijena (2016) [8] }\end{array}$ \\
\hline & Education & Avanzini (2015) [3]; Gerlach-Kristen (2018) [6]; Van Ooijena (2016) [8] \\
\hline & $\begin{array}{l}\text { Employment } \\
\text { conditions }\end{array}$ & $\begin{array}{l}\text { Gyourko (2014) [13]; Harrison (2011) [14]; Jones (2015) [15]; Lydon (2013) [7]; Van } \\
\text { Ooijena (2016) [8] }\end{array}$ \\
\hline & Family status & Csizmady (2017) [5]; Jones (2015) [15] etc. \\
\hline \multirow{6}{*}{ Transaction } & Initial LTV & $\begin{array}{l}\text { Avanzini (2015) [3]; Campbell (2015) [4]; Elul (2010) [9]; Foote (2018) [10]; Fuster (2015) } \\
\text { [11]; Goodman (2010) [12]; Harrison (2011) [14]; Hott (2015) [20]; Jones (2015) [15]; Kelly } \\
\text { (2018) [18]; Lee (2016) [16]; Lydon (2013) [7]; Van Ooijena (2016) [8] }\end{array}$ \\
\hline & Current LTV & $\begin{array}{l}\text { Avanzini (2015) [3]; Bian (2018) [21]; Campbell (2015) [4]; Elul (2010) [9]; Foote (2008) } \\
\text { [22]; Foote (2018) [10]; Fuster (2015) [11]; Gerlach-Kristen (2018) [6]; Goodman (2010) } \\
\text { [12]; Gyourko (2014) [13]; Hott (2015) [20]; Jones (2015) [15]; Kelly (2018) [18]; Lee } \\
\text { (2016) [16]; Lydon (2013) [7]; Van Ooijena (2016) [8] }\end{array}$ \\
\hline & $\begin{array}{l}\text { Interest rate } \\
\text { volatility }\end{array}$ & $\begin{array}{l}\text { Campbell (2015) [4]; Csizmady (2017) [5]; Foote (2018) [10]; Fuster (2015) [11]; Harrison } \\
\text { (2011) [14]; Hott (2015) [20]; Jones (2015) [15]; Van Ooijena (2016) [8] }\end{array}$ \\
\hline & $\begin{array}{l}\text { Foreign currency } \\
\text { loan }\end{array}$ & Beckmann (2015) [23]; Csizmady (2017) [5] \\
\hline & Loan to income ratio & $\begin{array}{l}\text { Campbell (2015) [4]; Figueira (2005) [24]; Fuster (2015) [11]; Gerlach-Kristen (2018) [6]; } \\
\text { Harrison (2011) [14]; Kukk (2016) [19]; Lee (2016) [16] }\end{array}$ \\
\hline & Negative equity & Aron (2016) [25]; Gerlach-Kristen (2018) [6]; Linn (2019) [26] etc. \\
\hline \multirow{5}{*}{ Macro factors } & GDP growth & Hott (2015) [20]; Lee (2016) [16] \\
\hline & House price index & $\begin{array}{l}\text { Aron (2016) [25]; Avanzini (2015) [3]; Campbell (2015) [4]; Foote (2018) [10]; Gerlach- } \\
\text { Kristen (2018) [6]; Harrison (2011) [14]; Hott (2015) [20]; Jones (2015) [15]; Lydon (2013) [7] }\end{array}$ \\
\hline & Income volatility & Foote (2018) [10] \\
\hline & $\begin{array}{l}\text { Interest rate } \\
\text { volatility }\end{array}$ & $\begin{array}{l}\text { Beckmann (2015) [23]; Campbell (2015) [4]; Fuster (2015) [11]; Goodman (2010) [12]; } \\
\text { Harrison (2011) [14]; Hott (2015) [20]; Lee (2016) [16] }\end{array}$ \\
\hline & Unemployment rate & $\begin{array}{l}\text { Aron (2016) [25]; Elul (2010) [9]; Foote (2018) [10]; Gerlach-Kristen (2018) [6]; Gyourko } \\
\text { (2014) [13]; Hott (2015) [20]; Lydon (2013) [7] etc. }\end{array}$ \\
\hline
\end{tabular}


Aron and Muellbauer (2016) based on mortgage data from UK analysis discovered strong correlation between arrears and aggregate debt-service ratio, the proportion of mortgages in negative equity and the unemployment rate [25]. Campbell and Cocco (2015) developed model incorporating household income, house price, inflation, and interest rate risk [4]. Created model highlights that mortgage default depends not only on the extent to which a borrower has negative home equity, but also on other factors, e.g. interest rates and income volatilities etc. Fuster and Willen (2012) also highlight the impact of negative equity and variations in interest rates on mortgages delinquencies [11]. They study was based on US mortgage micro-data. Gerlach-Kristen and Lyons (2018) applied regression analysis to national-level panel data to examine mortgage arrears in $15 \mathrm{EU}$ countries [6]. Researchers conclude that the isn't clear evidence that negative equity per se is associated with higher arrears, but the combination of affordability problems and negative equity, which makes it impossible for financially strained households to move to cheaper places and which the literature refers to as a dual trigger situation, seems to matter for longer-term arrears. Hott (2015) developed mortgage loss model calibration based on US and Switzerland data and conclude that loss rates are positively influenced by the house price level, the loan-to-value of mortgages, interest rates, and the unemployment rate, but negatively influenced by the growth of house prices and the income level [20]. Kelly and O'Toole (2018) found that default increases with originating loan-to-value and falling with origination debt service ratio [18].

The literature analysis provides some valuable guidance on housing loans risk drivers. The ability of borrowers to pay a mortgage can be affected by external circumstances such as unemployment and income decline, particularly during periods of crisis and recession, and by households themselves - the ability to balance their cash flow and competitiveness in the labour market. In the years of crisis, a sharp decline in housing prices is also playing an important role, and consequently less could refinance existing liabilities or sell mortgage without significant losses. Another important conclusion from the literature analysis is that there are different laws in different countries and consequently the results of studies cannot be interpreted unambiguously without taking into account these specificities.

\section{3- Macro Level Risk Drivers and Models}

\section{3-1- The Model}

Let $H o N P L_{\mathrm{t}}$ be dependent variable 'Housing loans nonperforming ratio' in year t. Further, let $x_{1 \mathrm{t}, \ldots, x_{\mathrm{kt}}}$ denote independent variables and $b_{\mathrm{it}}, \ldots, b_{\mathrm{kt}}$ denote regression coefficients of independent variables, than the model can be expressed as in Equation 1:

$H o N P L_{t}=f\left(x_{1 t}, \ldots, x_{k t}\right)+\varepsilon_{t}$

Where $\varepsilon_{t}-$ the error term.

\section{3-2- Data}

For research macro indicators on first stage where selected based on the literature review, indicators list, data source and correlation coefficients with 'Housing loans non-performing ratio' are presented in following table.

Table 2. Macro indicators and their correlation with HoNPL.

\begin{tabular}{lcccc}
\hline Indicator & Unit of measure & Abbreviation & Data source & Correlation \\
\hline Consumer price index & $\%$ & CPI & CSB [2] & $-0,4299$ \\
Foreign direct investments growth & $\%$ & FDI & BoL [27] & $-0,5826$ \\
GDP growth & $\%$ & GDP & CSB [2] & $-0,6371$ \\
House price index & $\%$ & HPI & CSB [2] & $-0,7016$ \\
Household disposable income growth & $\%$ & HDI & Eurostat [28] & $-0,8125$ \\
Household gross debt-to-income & $\%$ & GDI & Eurostat [28] & 0,5068 \\
Housing loans interest rate & $\%$ & HIR & ECB [29] & $-0,1665$ \\
Net wages growth & $\%$ & NWG & CSB [2] & $-0,7315$ \\
Unemployment rate & $\%$ & UPL & Eurostat [28] & 0,8885 \\
\hline
\end{tabular}

Macro indicators data for research where collected from Bank of Latvia (BoL) [27], Central Statistical Bureau of Latvia (CSB) [2], European Central Bank (ECB) [29] and Eurostat [28]. 
From table 2 one can see that the highest correlation with housing HoNPL in Latvia during years 2004-2018 showed following indicators: 'Unemployment rate' (0.8885), 'Household disposable income growth' (-0.8125), 'Net wages growth' (-0.7315), 'House price index' (-0.7016) etc. In the same time 'Housing loans interest rate' had low impact (-0.1665) on HoNPL, which isn't consistent with revealed in studies, e.g. Campbell (2015) [4], Csizmady, (2017) [5], Foote, (2018) [10], Fuster (2015) [11], Harrison (2011) [14], Hott (2015) [20] and Jones, (2015) [15].

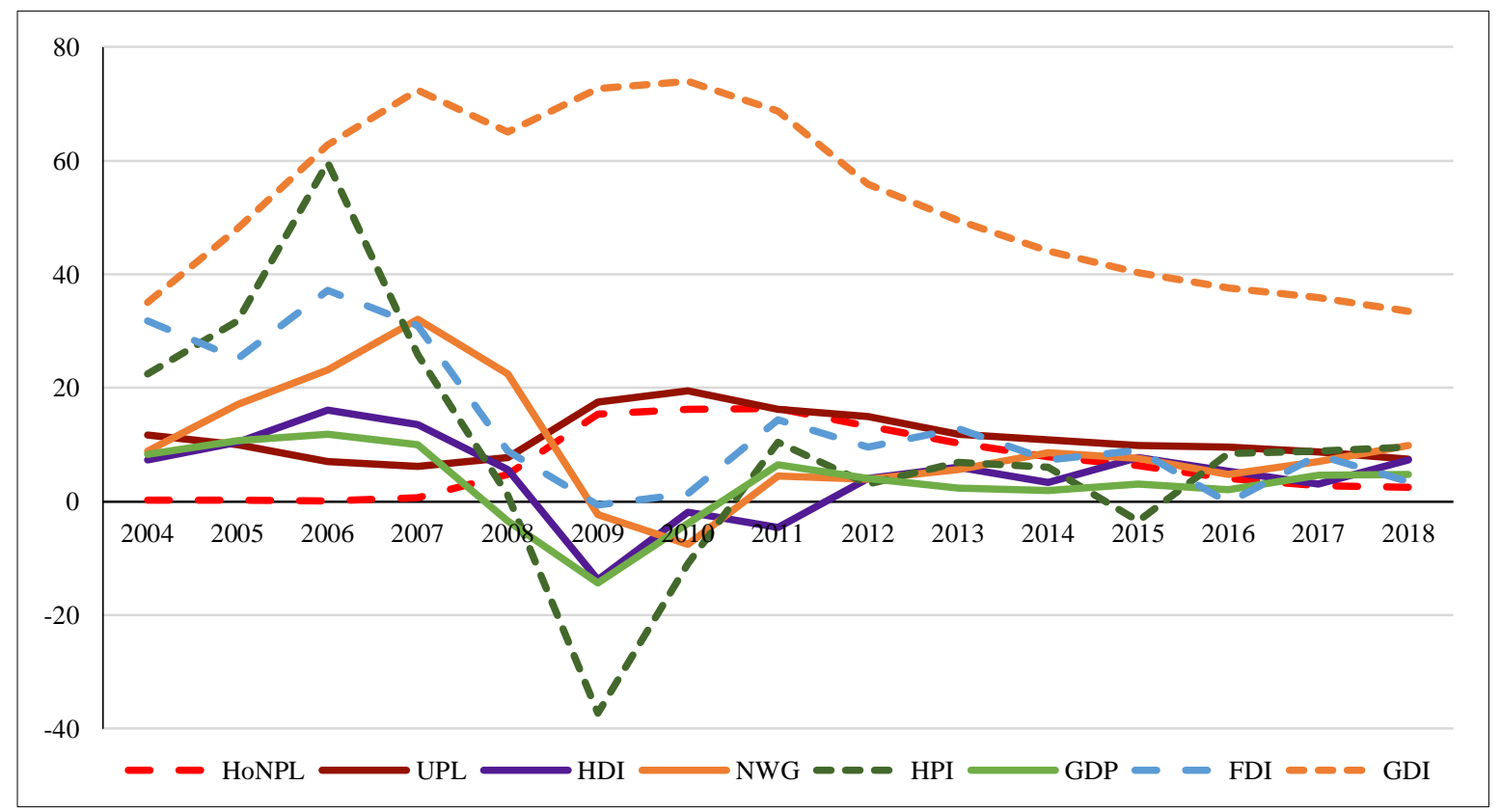

Figure 2. Macro indicators and HoNPL (Eurostat, BoL, FCMC, CSB of Latvia data).

\section{3-3-Results}

In the first stage based on the method of least squares 59 regression models ( 7 linear univariate, 7 nonlinear and 45 multivariate) have been created, which faced trough $F$ test at confidence level of $0.95(\alpha=0.05)$. In the second phase, those who failed regression coefficient statistical stability $t$-test at confidence level of 0.95 were removed. The statistics of regression models faced trough $t$-test are aggregated in following table.

Table 3. Final regression models statistics.

\begin{tabular}{ccccccc}
\hline$\#$ & Model type & Variable & $\boldsymbol{R}^{\mathbf{2}}$ & $\boldsymbol{F}$ & $\boldsymbol{p}$ - value & Durbin-Watson \\
\hline 1. & 1-factor, linear & UPL & 0.7895 & 48.7568 & $<0.0001 \%$ & 0.8687 \\
3. & 1-factor, linear & HDI & 0.6601 & 25.2500 & $<0.0001 \%$ & 0.8037 \\
5. & 1-factor, linear & NWG & 0.5351 & 14.9625 & $<0.0001 \%$ & 0.4347 \\
7. & 1-factor, linear & HPI & 0.4903 & 12.6018 & $<0.0001 \%$ & 0.6964 \\
9. & 1-factor, linear & GDP & 0.4058 & 8.8799 & $<0.0001 \%$ & 0.5330 \\
11. & 1-factor, linear & FDI & 0.3394 & 6.6789 & $<0.002 \%$ & 0.4991 \\
18. & 2-factor, linear & UPL, GDP & 0.9098 & 60.5098 & $<0.0001 \%$ & 0.7224 \\
20. & 2-factor, linear & UPL, GDI & 0.5787 & 8.2401 & $<0.0003 \%$ & 0.8415 \\
43. & 3-factor, linear & UPL, FDI, GDI & 0.9066 & 35.5770 & $<0.0001 \%$ & 2.5773 \\
44. & 3-factor, linear & UPL, HPI, GDI & 0.9478 & 66.6114 & $<0.0001 \%$ & 2.4345 \\
46. & 3-factor, linear & UPL, GDP, GDI & 0.9432 & 60.9273 & $<0.0001 \%$ & 1.9141 \\
47. & 3-factor, linear & UPL, FDI, HIR & 0.8338 & 18.3981 & $<0.0001 \%$ & 2.7174 \\
48. & 3-factor, linear & UPL, GDI, HST & 0.7330 & 10.0682 & $<0.0001 \%$ & 1.4827 \\
56. & 4-factor, linear & UPL, HDI, FDI, GDI & 0.9507 & 48.1749 & $<0.0001 \%$ & 1.7572 \\
\hline
\end{tabular}

Statistics in Table 3 show that 5 of the models created allow to explain at least $90 \%$ and three of them at least $94 \%$ of housing non-performing loans ratio fluctuations with changes in variables included. In order to compare those five model and select the model with highest statistical stability residuals were analyzed, see following figure. 


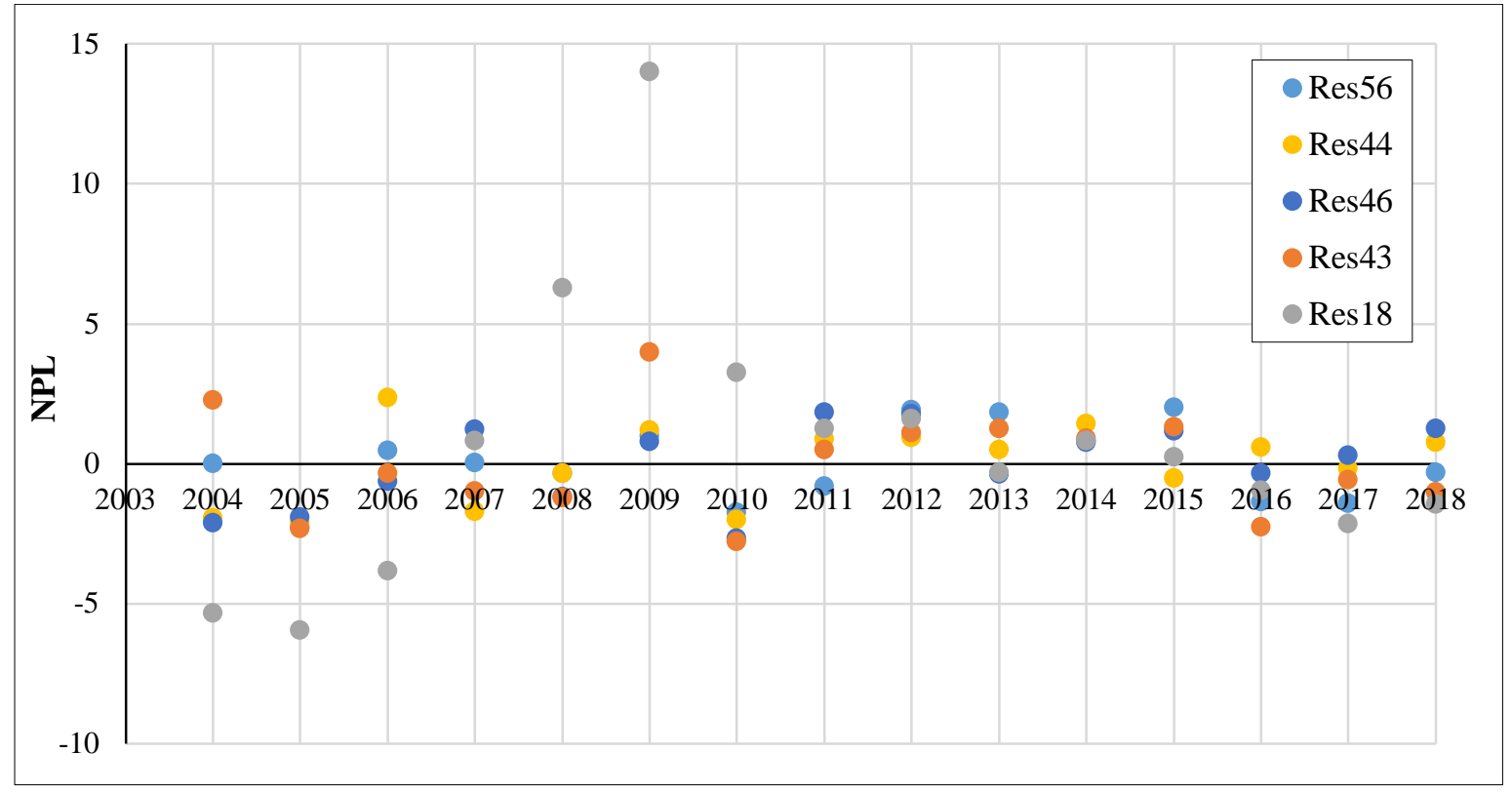

Figure 3. Best fit model's residuals.

Residuals analysis shows that all five models considered provide a sufficiently high level of stability and a minor error during periods of sustainable development, while in crisis years individual models, e.g. \#18, are becoming manifestly unstable.

Based on Durbin-Watson statistic the preference should go to model \#46:

$H o N P L_{t}=1,0551 * U P L_{t}-0,5896 * G D P_{t}+0,0794 * G D I_{t}-7,7595$

The results are statistically significant $(F=60.9273, p<0.00001 \%)$. Model (2) allow to explain $>94 \%$ of housing loans non-performing variations with $U P L_{t}, G D P_{t}$ and $G D I_{t}$ variations.

Table 4. Model \#46 regression coefficients and $p$-values

\begin{tabular}{lcl}
\hline Variable & Regression coefficient & $\boldsymbol{p}$-value \\
\hline Unemployment rate & 1.0551 & $0.0002 \%$ \\
Gross domestic product & -0.5896 & $0.0004 \%$ \\
Household gross debt-to-income & 0.0794 & $2.7194 \%$ \\
Intercept & -7.7595 & $0.2595 \%$ \\
\hline
\end{tabular}

\section{4- Micro Level Risk Drivers and Models}

\section{4-1- Data}

The primary data used in micro level study come from two housing loans samples - one include borrowers age, credit history, Loan-to-Value (LTV) and NPL status at the end 2011 and other at the end 2017. In order to solve NPL micro numerosity issues following indicators buckets were created:

- age - up to $25 ; 25-30 ; 31-35, \ldots$;

- credit history - score up to $10 ; 11-20 ; 21-30, \ldots$;

- LTV - up to $0.5 ; 0.5-0.6 ; 0.61-0.7, \ldots$

Following figures show borrowers age and NPL, credit history and NPL, LTV and NPL distributions. 


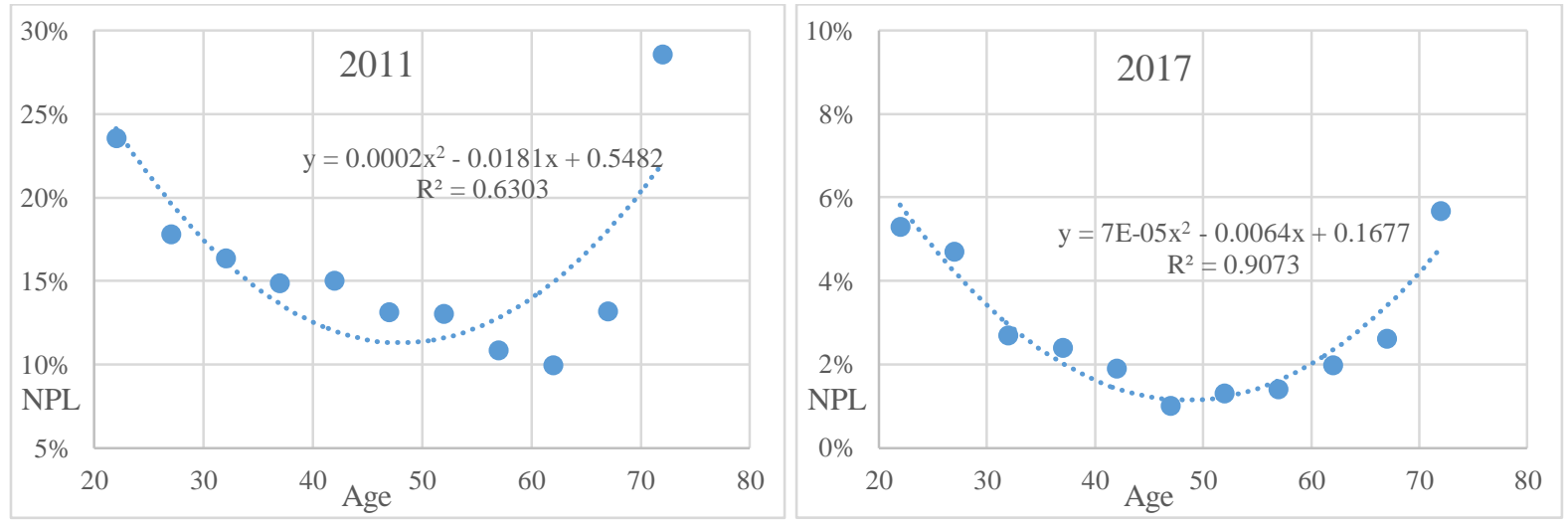

Figure 4. Borrowers age and NPL's distributions.
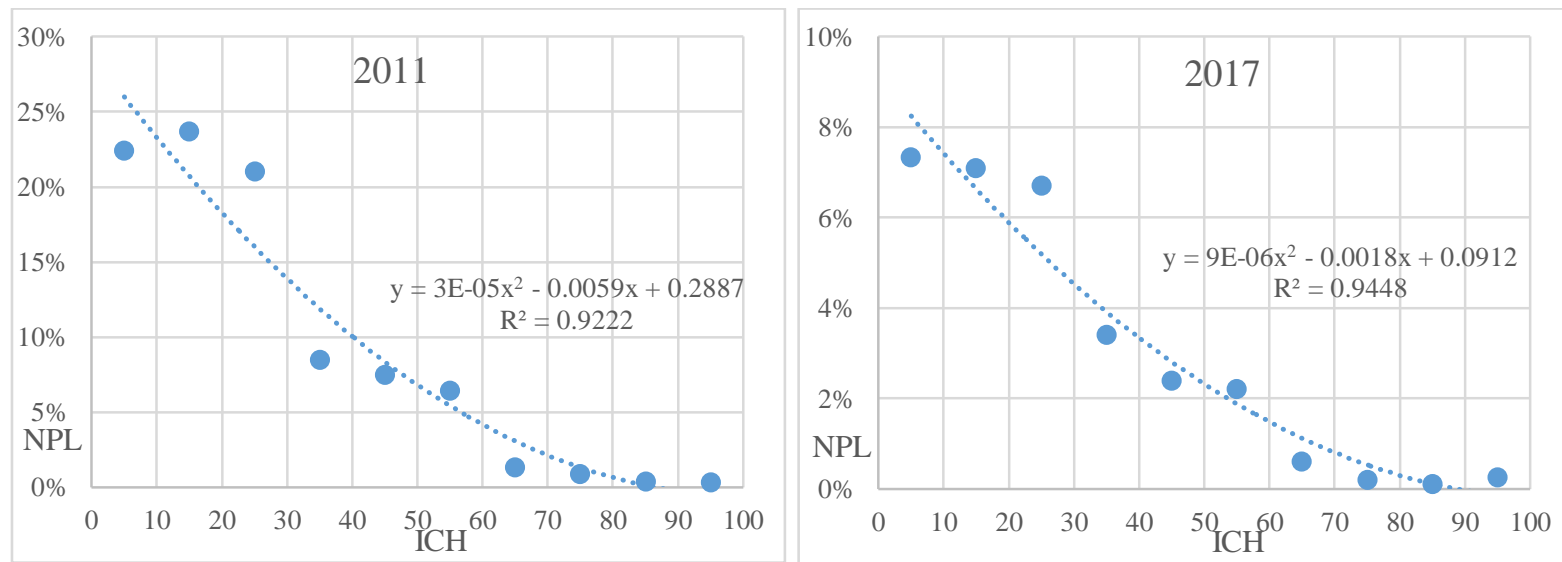

Figure 5. Credit history and NPL's distributions.
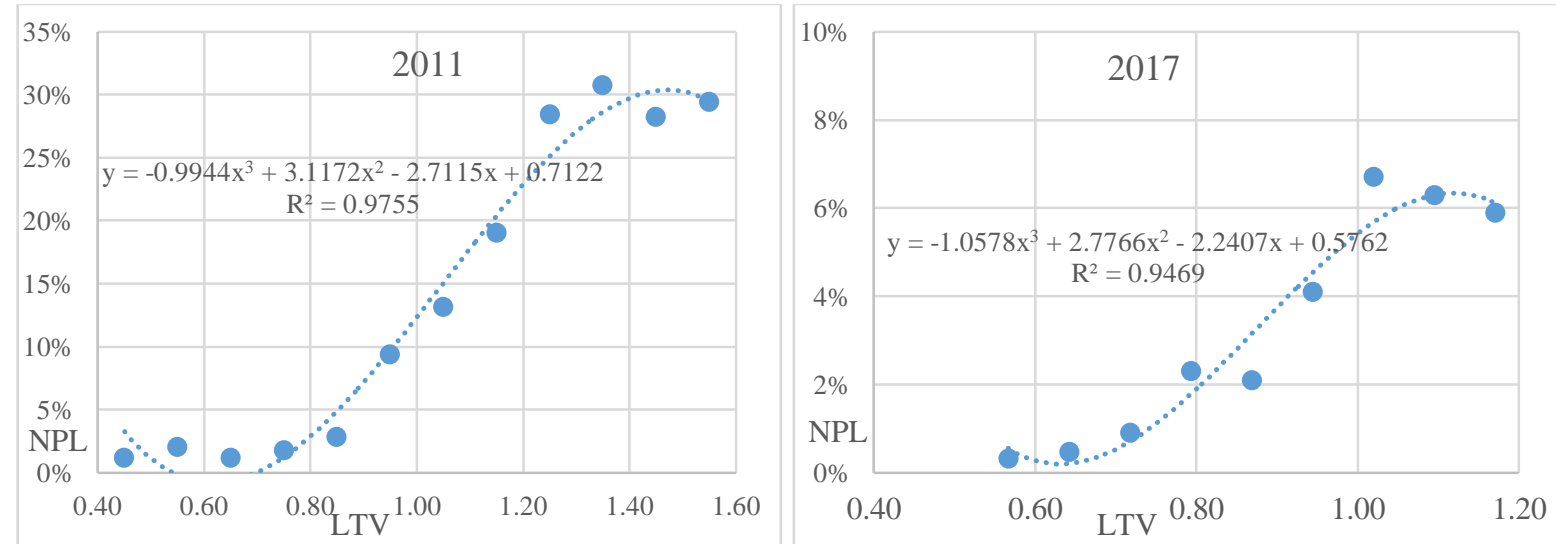

Figure 6. LTV's and NPL's distributions.

\section{4-2- Results}

Using method of least squares linear and nonlinear models were created. Best fit model's statistics are aggregated in following table.

Table 5. Best fit model's regression statistics.

\begin{tabular}{ccccccc}
\hline Model & Model type & $\boldsymbol{R}^{\mathbf{2}}$ & $\boldsymbol{S} \boldsymbol{F}$ & $\boldsymbol{p}$-value & $\boldsymbol{t}$-test $\max \boldsymbol{p}$-value \\
\hline Age2011 & Second order polyn. & 0.6303 & 0.0378 & 6.8186 & $1.869 \%$ & $<0.650 \%$ \\
Age2017 & Second order polyn. & 0.9073 & 0.0056 & 39.1297 & $0.007 \%$ & $<0.002 \%$ \\
ICH2011 & Second order polyn. & 0.9222 & 0.0302 & 41.5111 & $0.013 \%$ & $<6.064 \%$ \\
ICH2017 & Second order polyn. & 0.9448 & 0.0079 & 59.8934 & $0.004 \%$ & $<4.235 \%$ \\
LTV2011 & Third order polynom. & 0.9755 & 0.0230 & 106.219 & $0.0001 \%$ & $<0.395 \%$ \\
LTV2017 & Third order polynom. & 0.9469 & 0.0075 & 29.7198 & $0.130 \%$ & $<7.405 \%$ \\
\hline
\end{tabular}


Regression statistics show that the statistical stability of the models created is high $-F$-test $p$-values $<2 \%$. Also regressions coefficients $t$-tests demonstrate model's stability. All models allow explaining more than 90\% (except Age2011 with 63\%) of HoNPL fluctuations with changes in variables included. Comparing models with 'Age' as variable, it can be seen that this risk indicator works not so well in time periods with fragile economic development (recessions and crises). Borrower's credit history is as stable risk indicator for both stable and volatile economic conditions periods of time. Meanwhile, LTV is slightly better risk indicator in fast-changing house price periods of time.

Residuals are shown in following figures.

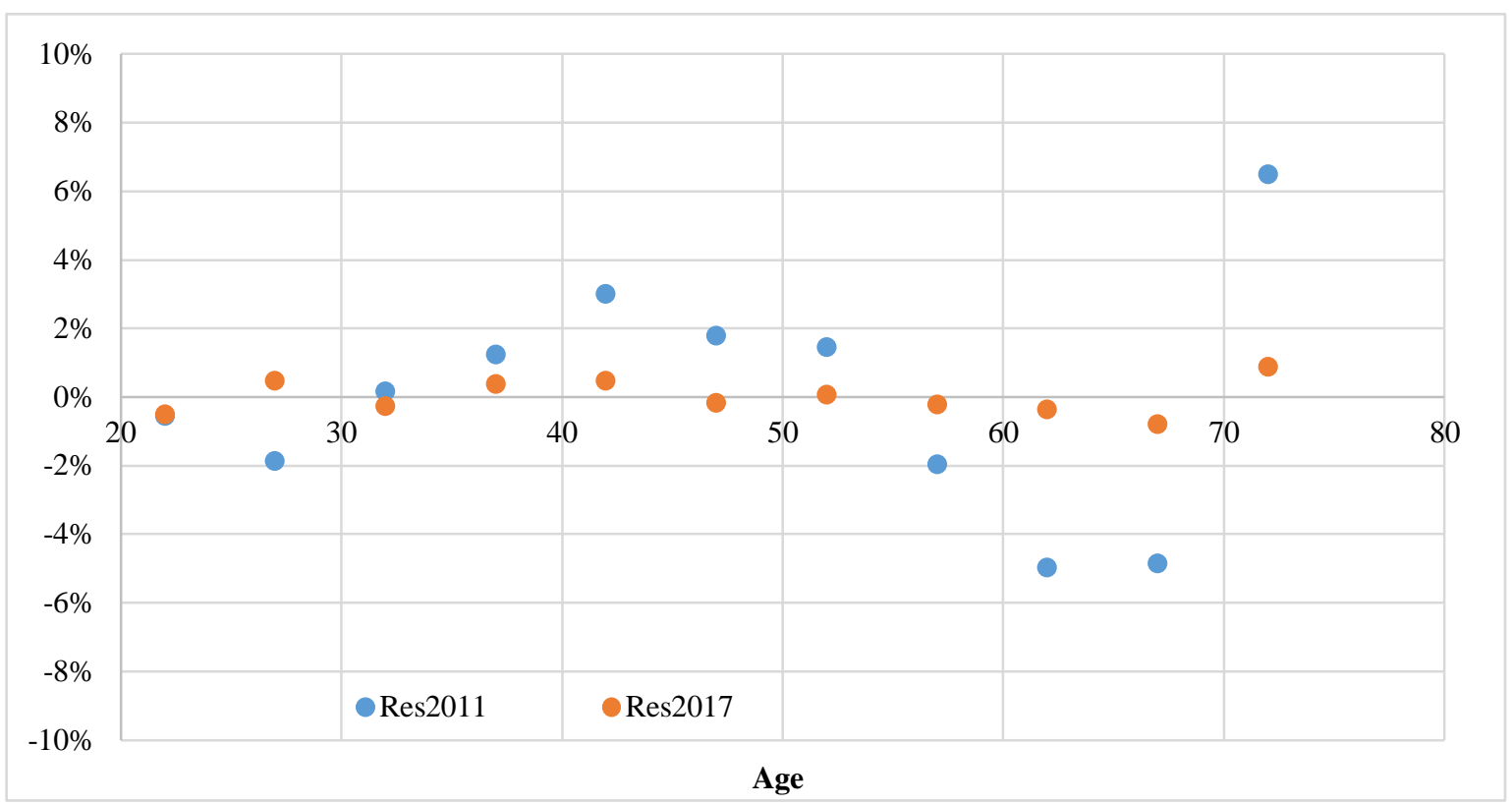

Figure 7. Residuals distributions for models with age.

Residuals analysis for created models with age shows that Age2017 provide a sufficiently high level of stability and a minor error for all age groups, while during crisis years forecasts for age $60+$ is related with high uncertainty.

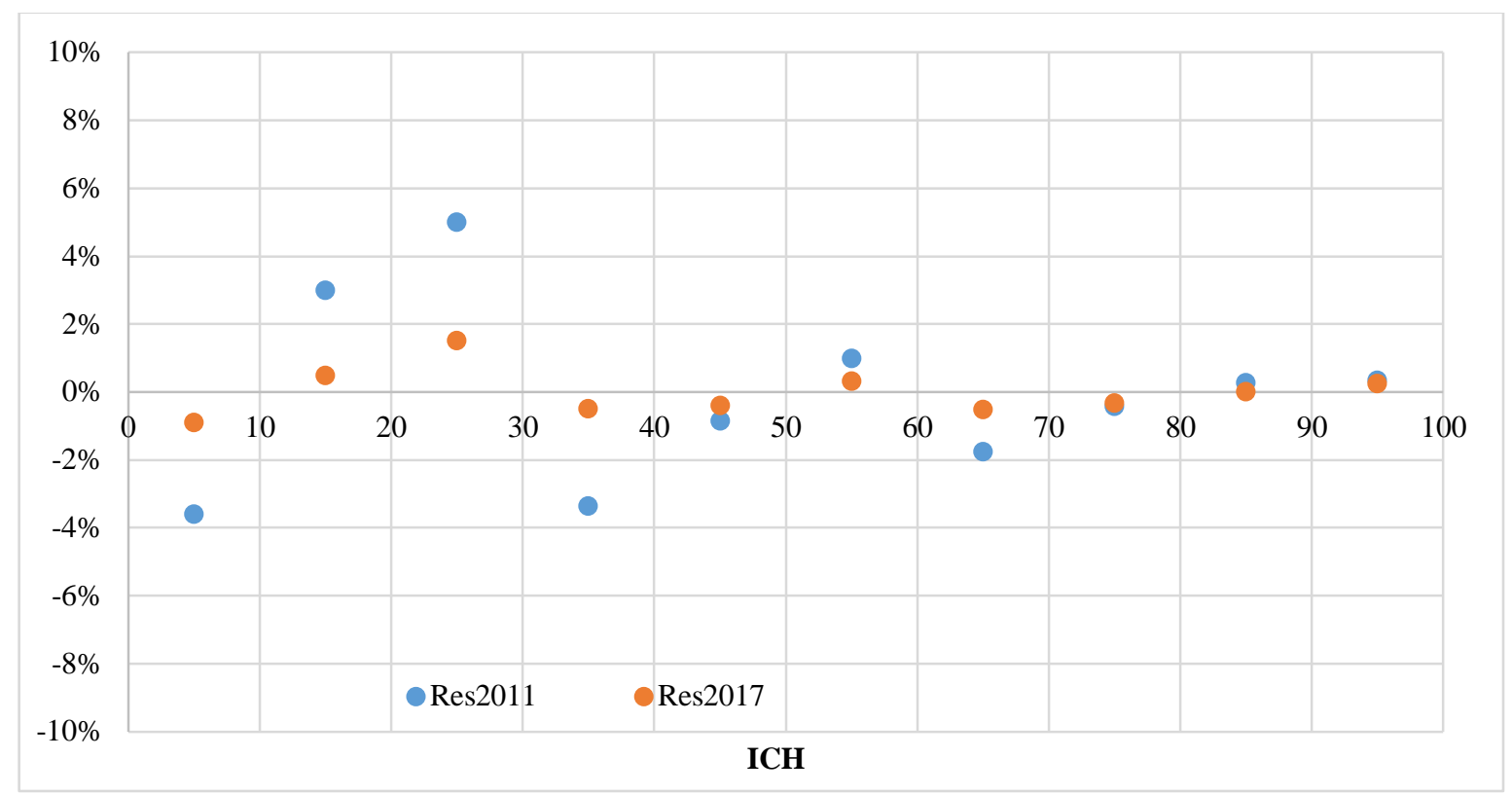

Figure 8. Residuals distributions for models with ICH.

Residuals analysis for created models with credit history shows that ICH2017 provide a sufficiently high level of stability and a minor error for all ICH scoring groups, while during crisis years forecasts for ICH scoring groups with risk 'above average' is related with high uncertainty. 


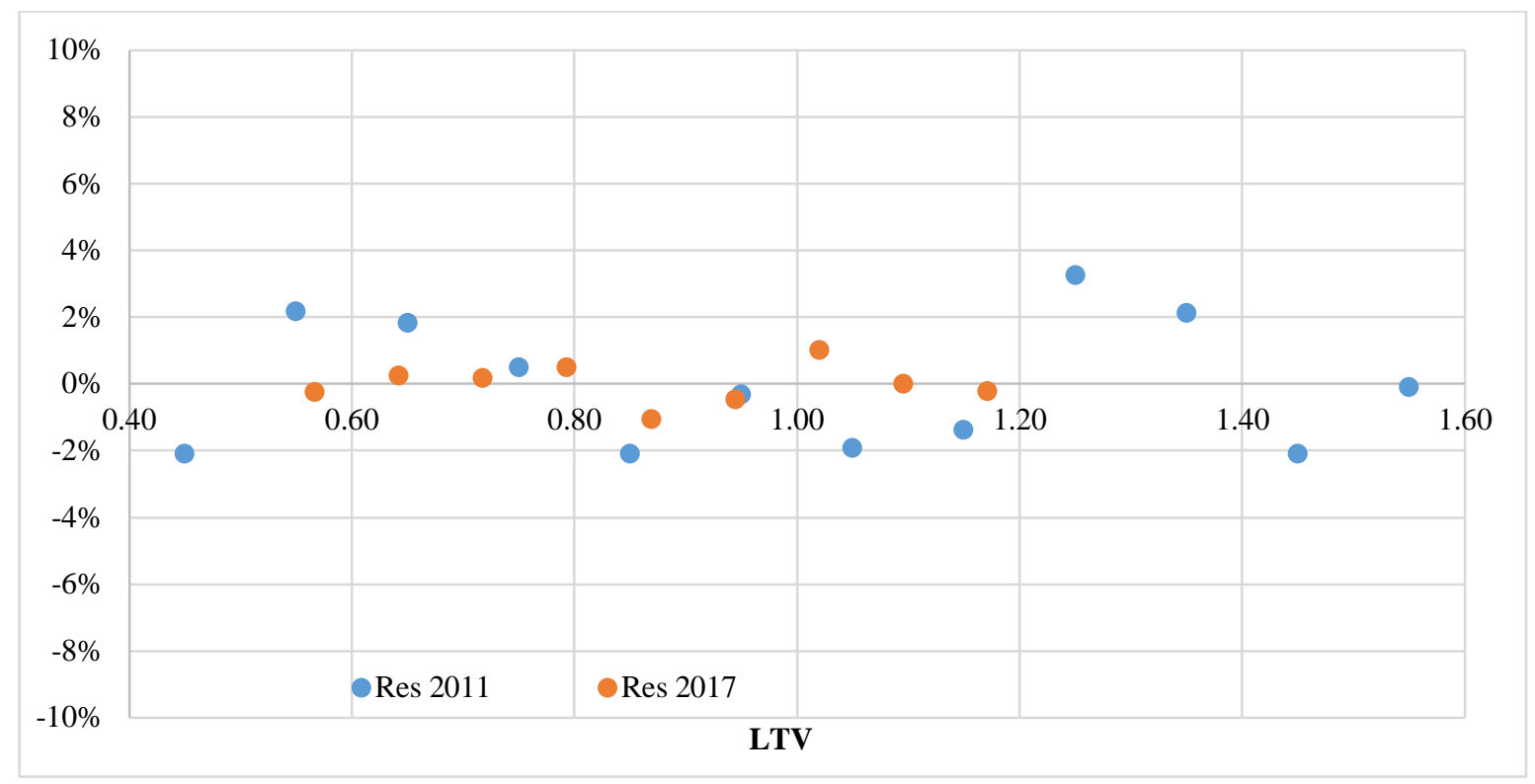

Figure 9. Residuals distributions for models with LTV.

Residuals analysis for created models with LTV shows that LTV2017 provide a sufficiently high level of stability and a minor error for all LTV buckets, while during crisis years forecasts for LTV buckets $125 \%+$ is related with high uncertainty.

\section{5- Conclusion}

The severe financial crisis and the subsequent slow recovery in Latvia have had a significant impact on both the banking business, suffering massive losses from not always sufficiently carefully evaluated credit applications and forcing a review of the credit approval standards set to date, as well as the housing market, which has stagnated for years after the crisis, and households which have been unable to repay often the commitments created.

It is important to identify both macro and micro risk drivers, since credit risk management tasks cover the assessment of the total risk of the credit portfolio in perspective, such as the amount of expected losses and capital requirements for covering credit risk for business plan and internal capital adequacy assessment needs, and the credit risk causation study to make sound business activation or risk mitigation decisions.

The quality of the analysis of household credit risks can be ensured by the availability of a number of models and the possibility of use them in combination to assess expected risk levels, as a weighted average of a number of outcomes, for example, taking into account the availability of indicator forecasts, the level of its assurance and other considerations. Before applying the models drawn up and framed, it is important not only to verify their statistical stability, but also to carefully assess model errors (residuals), as the research carried out shows that each model has different behaviour over different periods of the economic cycle and should not be ignored.

According to the research carried out, the most influential macro risks drivers for housing loans are unemployment, household gross disposable income, GDP, house price index, wages growth, and from micro drivers - credit history, age, LTV etc. The results of the study in this respect largely coincide with those previously carried out and described in accessible literature. However, in addition, it can be concluded that each of these indicators has both certain advantages and shortcomings, which differ in the various periods of economic development. It is important to remember that once created econometric models cannot be considered non-changeable - they should be regularly tested and recalibrated if necessary.

\section{6- Conflict of Interest}

The author declares that there is no conflict of interests regarding the publication of this manuscript. In addition, the ethical issues, including plagiarism, informed consent, misconduct, data fabrication and/or falsification, double publication and/or submission, and redundancies have been completely observed by the authors.

\section{7- References}

[1] FCMC Statistics (2019). Available online: https://www.fktk.lv/statistika/kreditiestades/ceturksna-parskati/ (accessed on 30 October 2019).

[2] CSB Database (2019). Available online: https://www.csb.gov.lv/en/statistika/db/ (accessed on 30 October 2019). 
[3] Avanzini Diego, Martinez Juan Francisco and Perez Victor. "A micro-powered model of mortgage default risk for full recourse economies, with an application to the case of Chile ". BIS (December 2015): 41.

[4] Campbell, John Y., and João F. Cocco. “A Model of Mortgage Default.” The Journal of Finance 70, no. 4 (July 23, 2015): 1495-1554. doi:10.1111/jofi.12252.

[5] Csizmady, Adrienne, József Hegedüs, and Gyula Nagy. "The Effect of GFC on Tenure Choice in a Post-Socialist Country - the Case of Hungary." International Journal of Housing Policy 17, no. 2 (March 17, 2017): $249-275$. doi:10.1080/19491247.2017.1293409.

[6] Gerlach-Kristen, Petra, and Seán Lyons. "Determinants of Mortgage Arrears in Europe: Evidence from Household Microdata." International Journal of Housing Policy 18, no. 4 (August 22, 2017): 545-567. doi:10.1080/19491247.2017.1357398.

[7] Lydon, Reamonn, and Yvonne McCarthy. "What lies beneath? Understanding recent trends in Irish mortgage arrears." The Economic and Social Review 44, no. 1, Spring (2013): 117-150.

[8] Van Ooijen, Raun, and Maarten C.J. van Rooij. "Mortgage Risks, Debt Literacy and Financial Advice.” Journal of Banking \& Finance 72 (November 2016): 201-217. doi:10.1016/j.jbankfin.2016.05.001.

[9] Elul, Ronel, Nicholas S Souleles, Souphala Chomsisengphet, Dennis Glennon, and Robert Hunt. "What 'Triggers' Mortgage Default?” American Economic Review 100, no. 2 (May 2010): 490-494. doi:10.1257/aer.100.2.490.

[10] Foote, Christopher L., and Paul S. Willen. "Mortgage-Default Research and the Recent Foreclosure Crisis." Annual Review of Financial Economics 10, no. 1 (November 2018): 59-100. doi:10.1146/annurev-financial-110217-022541.

[11] Fuster, Andreas, and Paul S. Willen. "Payment Size, Negative Equity, and Mortgage Default." American Economic Journal: Economic Policy 9, no. 4 (November 2017): 167-191. doi:10.1257/pol.20150007.

[12] Goodman, Allen C., and Brent C. Smith. "Residential Mortgage Default: Theory Works and so Does Policy." Journal of Housing Economics 19, no. 4 (December 2010): 280-294. doi:10.1016/j.jhe.2010.09.002.

[13] Gyourko, Joseph, and Joseph Tracy. "Reconciling Theory and Empirics on the Role of Unemployment in Mortgage Default." Journal of Urban Economics 80 (March 2014): 87-96. doi:10.1016/j.jue.2013.10.005.

[14] Harrison, David, and Thomas Noordewier. "Empirical evidence on mortgage choice as a screening mechanism for default risk." Journal of Housing research 20, no. 1 (2011): 1-18.

[15] Jones, Timothy, and G. Stacy Sirmans. "The underlying determinants of residential mortgage default." Journal of Real Estate Literature 23, no. 2 (2015): 167-205.

[16] Lee, Yongwoong, Daniel Rösch, and Harald Scheule. “Accuracy of Mortgage Portfolio Risk Forecasts During Financial Crises.” European Journal of Operational Research 249, no. 2 (March 2016): 440-456. doi:10.1016/j.ejor.2015.09.007.

[17] Figueira, Catarina, John Glen, and Joseph Nellis. "A Dynamic Analysis of Mortgage Arrears in the UK Housing Market." Urban Studies 42, no. 10 (September 2005): 1755-1769. doi:10.1080/00420980500231670.

[18] Kelly, Robert, and Conor O’Toole. "Mortgage Default, Lending Conditions and Macroprudential Policy: Loan-Level Evidence from UK Buy-to-Lets.” Journal of Financial Stability 36 (June 2018): 322-335. doi:10.1016/j.jfs.2018.03.008.

[19] Kukk, Merike. What are the triggers for arrears on debt? Evidence from quarterly panel data. No. wp2016-9. Bank of Estonia, 2016.

[20] Hott, Christian. "A Model of Mortgage Losses and Its Applications for Macroprudential Instruments." Journal of Financial Stability 16 (February 2015): 183-194. doi:10.1016/j.jfs.2014.06.005.

[21] Bian, Xun, Zhenguo Lin, and Yingchun Liu. "House Price, Loan-to-Value Ratio and Credit Risk.” Journal of Banking \& Finance 92 (July 2018): 1-12. doi:10.1016/j.jbankfin.2018.04.006.

[22] Foote, Christopher L., Kristopher Gerardi, and Paul S. Willen. "Negative Equity and Foreclosure: Theory and Evidence." Journal of Urban Economics 64, no. 2 (September 2008): 234-245. doi:10.1016/j.jue.2008.07.006.

[23] Beckmann, Elisabeth, and Helmut Stix. "Foreign Currency Borrowing and Knowledge About Exchange Rate Risk." Journal of Economic Behavior \& Organization 112 (April 2015): 1-16. doi:10.1016/j.jebo.2014.12.015.

[24] Figueira, Catarina, John Glen, and Joseph Nellis. "A Dynamic Analysis of Mortgage Arrears in the UK Housing Market." Urban Studies 42, no. 10 (September 2005): 1755-1769. doi:10.1080/00420980500231670.

[25] Aron, Janine, and John Muellbauer. "'Modelling and Forecasting Mortgage Delinquency and Foreclosure in the UK." Journal of Urban Economics 94 (July 2016): 32-53. doi:10.1016/j.jue.2016.03.005.

[26] Linn, Andrew, and Ronan C. Lyons. "Three Triggers? Negative Equity, Income Shocks and Institutions as Determinants of Mortgage Default.” The Journal of Real Estate Finance and Economics (July 31, 2019). doi:10.1007/s11146-019-09711-1.

[27] Bank of Latvia (2019). Available online: https://statdb.bank.lv/lb/ (accessed on 30 October 2019).

[28] Eurostat (2019). Available online: https://ec.europa.eu/eurostat/ (accessed on 30 October 2019).

[29] ECB (2019). Available online: https://sdw.ecb.europa.eu/ (accessed on 30 October 2019). 